\title{
Orofacial Pain Prospective Evaluation and Risk Assessment Study - The OPPERA Study
}

\author{
William Maixner ${ }^{1,2,3}$, Luda Diatchenko ${ }^{1,2,4}$, Ronald Dubner ${ }^{5}$, Roger B. Fillingim ${ }^{6}$, Joel D. \\ Greenspan $^{5}$, Charles Knott ${ }^{7}$, Richard Ohrbach ${ }^{8}$, Bruce Weir ${ }^{9}$, and Gary D. Slade ${ }^{1,10,11}$ \\ ${ }^{1}$ Center for Neurosensory Disorders, University of North Carolina at Chapel Hill Chapel Hill, NC \\ ${ }^{2}$ Department of Endodontics, University of North Carolina at Chapel Hill Chapel Hill, NC \\ ${ }^{3}$ Department of Pharmacology, University of North Carolina at Chapel Hill Chapel Hill, NC \\ ${ }^{4}$ Carolina Center for Genome Sciences at Chapel Hill Chapel Hill, NC \\ ${ }^{5}$ Department of Neural and Pain Sciences, and Brotman Facial Pain Center, University of \\ Maryland Dental School, Baltimore, MD \\ ${ }^{6}$ Department of Community Dentistry \& Behavioral Science, University of Florida, Gainesville, FL \\ ${ }^{7}$ Battelle Memorial Institute, Durham, NC \\ ${ }^{8}$ Department of Oral Diagnostic Services, University at Buffalo, Buffalo, NY \\ ${ }^{9}$ Department of Biostatistics University of Washington Seattle, WA \\ ${ }^{10}$ Department of Dental Ecology, University of North Carolina at Chapel Hill, Chapel Hill, NC \\ ${ }^{11}$ Department of Epidemiology, University of North Carolina at Chapel Hill Chapel Hill, NC
}

This Journal of Pain Compendium presents the initial outcomes from the first large population-based study designed to identify the biopsychosocial and genetic risk factors that contribute to the onset and persistence of painful temporomandibular joint disorders (TMD) - The OPPERA Study. This study is supported by NIDCR Cooperative Agreement U01 DE017018 that was initiated September 22, 2005.

\section{Overview}

Temporomandibular disorders (TMD) consist of a heterogeneous family of musculoskeletal disorders that represent the most common chronic orofacial pain condition ${ }^{16,17,57}$.

(C) 2011 The American Pain Society. Published by Elsevier Inc. All rights reserved.

Correspondence to: OPPERA Study, Center for Neurosensory Disorders, Rm 2111 Old Dental Building, University of North Carolina, Chapel Hill, N.C. 27599-7455, 919-966-0684 (Telephone), 919-966-3683 (FAX).

Disclosures

This work was supported by NIH grant U01DE017018 and P01NS045685. This material was also supported with by the North Florida/South Georgia Veterans Health System, Gainesville, FL. The OPPERA program also acknowledges resources specifically provided for this project by the respective host universities: University at Buffalo, University of Florida, University of MarylandBaltimore, and University of North Carolina-Chapel Hill. Roger Fillingim and Gary Slade are consultants and equity stock holders, and William Maixner and Dr. Luda Diatchenko are officers and equity stock holders in Algynomics, Inc., a company providing research services in personalized pain medication and diagnostics. Portions of these data were presented at the 2010 Annual Scientific Meeting of the American Pain Society in Baltimore, MD.

Publisher's Disclaimer: This is a PDF file of an unedited manuscript that has been accepted for publication. As a service to our customers we are providing this early version of the manuscript. The manuscript will undergo copyediting, typesetting, and review of the resulting proof before it is published in its final citable form. Please note that during the production process errors may be discovered which could affect the content, and all legal disclaimers that apply to the journal pertain. 
Debilitating forms of TMD are associated with persistent pain in the region of the temporomandibular joint, the periauricular region, and muscles of the head and neck ${ }^{16,17,57}$. Five percent of US adults in the 2002 National Health Interview Survey reported TMD-type pain ( $6 \%$ of women, and $3 \%$ of men $)^{35}$, while an examination-survey of a representative sample of females in New York City found that $10 \%$ had examinerdiagnosed $\mathrm{TMD}^{36}$. Individuals with TMD rate the intensity of its pain at 4.3 , on average, using a $0-10$ scale, which is comparable to the average intensity rating of 4.7 for back pain among people with that condition ${ }^{70}$. While the natural history of TMD has not been well studied, TMD has been reported to remit over a 5-year observational period in 33 to $49 \%$ of diagnosed cases and to remain persistent or recurrent in the remainder ${ }^{56,59}$.

TMD exerts a considerable burden on the population. It has been estimated that TMD results in 17,800,000 lost work days per year for every 100,000,000 working adults in the United States ${ }^{18}$ and that approximately $85 \%$ of the cost of treating TMD is associated with the treatment of a small portion of the patients who develop persistent pain and dysfunction ${ }^{25}$. As such, there is a substantial need to identify the risk factors that lead to the onset and maintenance of TMD.

Most epidemiological studies of TMD have been limited to cross-sectional or case-control designs and have largely relied on convenience samples. These studies consistently report higher prevalence in females than in males, with a female to male ratio ranging from 2 to 1 in the general population to 8 to 1 in clinical settings ${ }^{4,66}$. Numerous risk factors have been implicated, including: joint and muscle trauma, anatomical factors (e.g., skeletal and occlusal relationships), pathophysiological factors (e.g., bone and connective tissue disorders, hormonal differences, sensitization of peripheral and central nervous system pain processing pathways) and psychosocial factors (e.g., depression and anxiety, emotional and perceptual responses to psychological stressors) $)^{6}$. However, due to the cross sectional study design of these studies, it remains unclear if many of those putative risk factors predated TMD onset, and therefore represent causal influences on the risk of developing TMD the condition, or whether the putative risk factors were a consequence of TMD.

Significant improvements in study design occurred with the work of Dworkin and colleagues who led the development of valid and reliable diagnostic methods and undertook a prospective study of enrollees in the Group Health Cooperative of Puget Sound ${ }^{6,16,70,71 .}$ At baseline, they estimated the prevalence of painful TMD to be $12.1 \%$, with a female to male ratio of approximately 2:1. Based on TMD symptoms reported in follow-up interviews, the annual incidence of TMD was $2 \%$, with females tending to show a higher incidence rate than males ${ }^{71}$. Two risk factors were predictive of elevated incidence of TMD: a reported history of pain at other bodily sites, and positive responses to questions associated with depression. In the only prospective cohort study to have used clinical examinations to diagnose first-onset TMD, the annual incidence rate was 3.5\% in the cohort of 171 females aged 18-34 years who were followed for up to three years. ${ }^{11,64}$

Based on the preceding evidence and the biopsychosocial model of TMD proposed by Dworkin and coworkers ${ }^{15}$, we created a heuristic model of causal influences contributing to onset and persistence of TMD and related conditions (Figure 1) ${ }^{12}$. This model proposes that TMD, and its associated signs and symptoms, are influenced most proximally by two sets of intermediate phenotypes: psychological distress and pain amplification. Each of those intermediate phenotypes represents a constellation of more specific risk factors located distally in this causal web, (e.g. risk factors contributing to pain amplification include proinflammatory states, impaired pain regulation, cardiovascular function and neuroendocrine function). There probably are synergistic effects between the two main intermediate phenotypes, such that the effect on TMD of one intermediate phenotype is enhanced by the 
other intermediate phenotype. Meanwhile, interactions between intermediate phenotypes and the contributions of more distal risk factors all take place in the presence of environmental contributions that further contribute to onset and persistence of painful TMD. The most distal contribution comes from genetic regulation of biological mechanisms that determine expression of intermediate phenotypes and their associated risk factors. Time is not depicted in the model, because its effects occur implicitly on a third dimension that is not readily shown in the diagram. However, time is recognized as an inevitable consideration in models of risk for chronic pain, because passage of time is a requirement for development of chronic pain.

\section{Socio-demographic and clinical factors predictive of TMD}

In cross-sectional and case-control studies, frequency of TMD is consistently greater in females than in males. In adults, age-specific prevalence displays an inverted U relationship, being greatest among people in their 40s, and lower in both younger and older age groups. However, in the prospective cohort study of TMD conducted among HMO enrollees in Seattle, WA, ${ }^{71}$ the risk of developing TMD, as reported by subjects who completed followup interviews, was only marginally elevated for females compared with males (relative risk $=1.6, \mathrm{P}>0.10)$. There were progressively lower incidence rates of TMD onset among people aged 45-64 and 65+ compared with 18-44 year olds, although the differences were not statistically significant. The more robust gender differences in prevalence observed in studies of clinic-based vs. population-based samples suggest that gender-related factors are more strongly associated with health care seeking and perhaps severity of the condition than with TMD onset per se.

While it is clear that race and ethnicity are associated with clinical and laboratory pain reporting $19,20,28$, their role as risk factors for TMD onset is unknown. Because lower socioeconomic status is frequently confounded with ethnic and racial status in the US, the actual role of culture, ethnicity or race, as risk factors is similarly unknown, but obviously merits attention for both scientific and public health reasons ${ }^{28}$. Plesh and colleagues ${ }^{58}$ reported that after adjusting for socio-economic status, facial pain was significantly more common among Caucasian compared to African American women between the ages of 19 and 23. Consequently, the reliable demographic factors associated with prevalence of TMD pain remain gender and age. The primary clinical factor associated with TMD pain onset is the presence of other pain conditions $2,29,37,42$ although prospective cohort studies of people with TMD report that baseline TMD clinical findings themselves are remarkably unrelated to the progression of TMD pain ${ }^{56,59}$. There remains a substantial need to determine the incidence of TMD onset and persistence in the population.

\section{Pain Amplification as a Determinant of TMD Onset and Persistence}

The second specific scientific aim of the OPPERA study examines the role of pain amplification in the onset and persistence of TMD. "Pain amplification" refers to alterations in peripheral and central nervous system processes that have the net effect of amplifying the perceptual response to nociceptive stimuli. Pain amplification is conceptualized as a general construct that subsumes more specific phenomena (e.g., hyperalgesia, allodynia, central sensitization). The mechanisms contributing to pain amplification are believed to include both decreased function in pain inhibitory systems and enhancement in pain facilitatory pathways. Pain amplification represents both a trait-like characteristic potentially conferred by genetic endowment, but also a phenotype that can develop over time in response to emergent biological processes and/or environmental exposures. Pain amplification manifests as heightened responsiveness to quantitative sensory testing as well as spontaneous clinical pain from deep tissues such as muscles, joints and visceral organs. 
In one of the few prospective studies of TMD onset, the most consistent predictor of developing a chronic pain disorder was the presence of another chronic pain condition at the baseline session ${ }^{70}$. Factors that influence pain sensitivity, psychological factors, and symptom perception may contribute to the development of a variety of chronic pain conditions independent of anatomical sites. Other prospective studies have shown widespread pain is a risk indicator for dysfunction associated with painful $\mathrm{TMD}^{37}$ and predicts lack of response to treatment.

The outcomes of several case-control studies suggest that TMD risk is influenced by a state of pain amplification ${ }^{43-45,63}$. Specifically, in comparison to TMD-free controls: 1) TMD cases report lower thresholds of pain in response to mechanical pressure applied to the face or wrist; 2) TMD cases report greater magnitude estimates of pain in response to heat pulses applied to the face or the forearm; 3) TMD cases show greater temporal summation (i.e., wind-up) of pain to repetitive thermal and mechanical stimuli; and 4) TMD cases demonstrate lower pain thresholds and tolerances to arm ischemia. In one of the few prospective studies of clinically-diagnosed, first-onset TMD, individuals who were sensitive to noxious stimuli were significantly more likely to develop painful TMD than those who were less pain sensitive (risk ratio $=2.7$ ). ${ }^{11}$ An important yet unresolved question is whether baseline pain sensitivity influences the severity and persistence of pain experienced by individuals who develop TMD. It has been shown that severity of TMD-related pain reported by patients with TMD is associated with their sensitivity to standardized noxious stimuli ${ }^{24}$ and a possible linkage of pain persistence with clinical measures of pain report has been suggested ${ }^{21}$. There remains a substantial need to determine whether pain sensitivity is a risk factor for TMD onset and persistence.

\section{Psychological Determinants of TMD Onset and Persistence}

In addition to pain amplification, multiple psychological factors have been implicated as potential risk factors for the development of painful TMD. Several studies have reported that patients with TMD express high levels of depression, and anxiety 5, 39, 69, and exhibit more frequent symptoms of stress than pain-free controls ${ }^{3}$. Yet, Von Korff and coworkers ${ }^{70}$ reported no relationship between rates of onset of back pain, abdominal pain or painful TMD and severity or chronicity of depressive symptoms. Furthermore compared to nondepressed subjects, subjects with moderate to severe depressive symptoms are about equally likely to develop TMD (odds ratio of 1.2 to 1.6).

A more than two-fold elevation in odds of TMD has been associated with relatively high levels of somatic awareness ${ }^{59}$, which is the tendency to report numerous physical symptoms in excess of that which can be explained by clinically signs and symptoms ${ }^{22}$. In a longitudinal study, Ohrbach and Dworkin ${ }^{56}$ reported that somatic awareness scores decreased in TMD patients who reported substantial improvement in facial pain after 5 years and that baseline somatic awareness scores predicted levels of pain following treatment ${ }^{46}$. Somatic awareness is also highly associated with widespread pain and the number of muscle sites painful to palpation ${ }^{72}$, as well as with progression from acute to chronic $\mathrm{TMD}^{26}$. In a prospective study that of 171 initially TMD free females followed for up to three years, we found that anxiety, depression and perceived stress each were significant risk factors for examiner-verified TMD onset (risk ratios ranging from 2.1 to 6.0) ${ }^{64}$. Given these findings, there is a substantial need to document the relationship between pre-existing psychological characteristics and the onset and persistence of TMD.

\section{Genetic Factors Influencing the Risk of TMD Onset and Persistence}

Genetic variants that impact pain sensitivity and psychological traits, when coupled with environmental factors such as physical or emotional stress, may interact to produce a 
phenotype that is vulnerable to TMD (see Figure 1). As recently reviewed by Diatchenko et al. ${ }^{13}$ both clinical and experimental pain perception are influenced by genetic factors $8,11,50,54,76$. Although the relative importance of genetic versus environmental factors in human pain perception remains unclear, reported heritability for nociceptive and analgesic sensitivity in mice is estimated to range from $28 \%$ to $76 \%{ }^{50}$, and similar heritability estimates have been reported for clinical pain and experimental pain sensitivity in humans ${ }^{54,55}$. Several recent studies have also established a genetic association with a variety of psychological traits and disorders. Comparisons of concordance rates in dizygotic and monozygotic twins have established that $30 \%-50 \%$ of the individual variability in risk to develop a given anxiety disorder is due to genetic factors ${ }^{27}$. The heritability of unipolar depression appears to be remarkable, with estimates between $40 \%$ and $70 \%{ }^{41}$.

Given the multifactorial nature of TMD, a large number of genetic variants are expected to contribute to the risk of TMD onset and persistence ${ }^{13}$, Advances in high throughput genotyping methods have led to discoveries that numerous genes are associated with TMD depression, anxiety, stress response, somatic awareness, affective disorders, and chronic pain has increased within the last few years. The same psychological characteristics are hypothesized to be intermediate phenotypes for TMD in the OPPERA heuristic model. A partial list includes genes that encode serotonin transporter $(5-H T T)^{7,27,41}$, cyclic AMPresponse element binding protein $1(C R E B 1)^{75}$, monoamine oxidase $\mathrm{A}(M A O A)^{10,38}$, serotonin $1 \mathrm{~A}$ and $1 \mathrm{~B}$ receptors ${ }^{27,41,52,68}$, catecholamine-O-methyltransferase $(C O M T)^{1,11,14,30,31,38,48}$, GABA-synthetic enzyme $G A D 65^{65}$, D2 dopamine receptor $(D R D 2)^{40}$, glucocorticoid receptor $(G R)^{73}$, interleukines 1 beta $(I L 1 \beta)$ and alpha $(I L 1 \alpha)^{47,62,74}$, interleukine receptor antagonist $(\mathrm{IL} 1 \mathrm{ra})^{67}, \mathrm{Na}+\mathrm{K}+$-ATPase (ATP1A2), potassium channel alpha subunit $\mathrm{KCNS} 1^{9}$ and voltage gated calcium channel subunits $C A C N A 1 A^{23}$ and $C A C N A 2 D 3^{53}$. For a comprehensive review see Diatchenko and coworkers $^{13}$. Because of interrelationships among several of these psychological variables, which are associated with chronic pain conditions, it is expected several of the identified genes will influence multiple psychological variables. As an example, it is known that, common polymorphisms in the promoter of 5-HTT gene are associated with depressive symptoms, diagnosable depression, suicidality in relation to stressful life events ${ }^{7,41}$, anxiety-related personality traits ${ }^{27}$, somatic awareness, and the development of TMD ${ }^{34}$.

To date, studies examining the heritability of painful TMD using twins and family-linkage studies have failed to identify a genetic basis to this disorder ${ }^{32,49,60}$. Assuming the multifactorial nature of TMD, these studies would require several thousand cases to have sufficient power to measure the heritability of $\mathrm{TMD}^{61}$. The largest study conducted on TMD patients included only 494 twins ${ }^{49}$, which as noted by the authors to be under powered and had less than $50 \%$ statistical power to assess the heritability of the disorder. Twin studies that have identified a genetic component to chronic pain traits have employed considerably larger sample sizes. For example, estimation of heritability for common migraine, which ranges from $34 \%$ to $57 \%$, required a total of 29,717 twin pairs from six countries ${ }^{51}$. Heritability of sciatica, which is estimated to be $20.8 \%$, required 9,365 twin pairs to $\operatorname{detect}^{33}$. Given the multifactorial nature of TMD, and the requirement for very large population sizes to detect heritability in a twin study design it is not surprising that previous approaches that have relied on under powered twin and sib pair studies have failed to identify a genetic basis to this disorder. In contrast to these previous studies, we $\mathrm{e}^{11}$ and others ${ }^{34}$, have successfully implemented association study designs with modest numbers of subjects (202 and 111, respectively) to identify and characterize polymorphisms in specific genes (i.e, COMT, $\beta 2-\mathrm{AR}$, and 5HT transporter genes) that are associated with pain processing and risk of TMD development. These positive findings have been enabled by the greater statistical power produced by an association study design that assesses the contributions of multiple genes to common multifactorial diseases compared to a familial- 
based linkage study that are capable of identifying relatively rare genetic variants that contribute to single gene disorders with high phenotypic penetrance. ${ }^{61}$ There remains a substantial need to identify genetic factors associated with the risk of TMD onset and persistence.

OPPERA is the first large prospective study that has been specifically designed to examine and identify biopsychosocial, environmental and genetic factors that contribute to the onset and persistence of TMD. To accomplish the aims of OPPERA, a group of internationally recognized scientists, with expertise in epidemiology, pain mechanisms, TMD diagnostics, functional genomics, statistical genetics, bioinformatics, and biostatistics, in collaboration with a highly recognized Data Coordinating Center (Battelle Memorial Institute) and the National Institutes of Dental and Crainiofacial Research initiated a 7-year prospective cohort study titled: Orofacial Pain Prospective Risk Evaluation and Assessment Study (see www.OPPERA.org; Cooperative Agreement U01 DE017018). The primary goal of the OPPERA study is to identify the psychological and physiological risk factors, clinical characteristics and associated genetic mechanisms that influence the development of TMD (i.e., factors that lead to the onset of TMD). Additionally, this study seeks to characterize the biological pathways through which these genetic variations causally influence TMD risk.

The stated methodological goals of OPPERA were to:

a. Undertake a prospective cohort study of 3,200 initially TMD-free individuals recruited from major ethnic and racial strata at four study sites, identifying an anticipated 204 incident cases of first-onset-TMD during a 5-year follow-up period.

b. Undertake a case-control study by recruiting 192 people with chronically symptomatic TMD identified during cohort recruitment whose history of TMD precludes them from enrolment in the prospective study.

c. Measure in both groups predictors of TMD risk, including both non-causal predictors (Aim 1) and etiological factors (Aims 2-4), analyzing their individualand joint-effects using a conceptual, causal model for TMD that we have developed based our own studies and other published research.

These epidemiological data will be used to address four specific scientific aims to determine if:

1. Socio-demographic characteristics thought to be predictive of TMD (e.g., younger age, female sex, white race) are associated with elevated risk of first-onset TMD and increased odds of chronic TMD;

2. Heightened responsiveness to noxious stimuli, delivered using standardized pain measurement procedures, together with biological processes associated with this heightened responsiveness (e.g. resting arterial blood pressure) contribute to the risk of first-onset TMD;

3. Pre-existing psychosocial profiles commonly observed with chronic pain conditions (e.g., depression, somatic awareness, anxiety, perceived life stress and stressful life events) are associated with elevated risk of first-onset TMD; and

4. Genetic variations in candidate genes that influence pain amplification and psychological profiles are associated with elevated risk of first-onset and chronic TMD; and if so, to identify the biological, psychological and clinical pathways through which these genetic variations causally influence TMD risk.

In this first set of manuscripts we describe study designs and data collection methods for the four studies that comprise OPPERA. Data from the OPPERA baseline case-control study of 
chronic TMD are used to investigate associations between occurrence of TMD and five domains of putative risk factors: sociodemographics, clinical characteristics, responses to standardized noxious stimuli measuring pain amplification, measures of cardiovascular function, psychological characteristics, and a selected panel of over 300 genes thought to be involved in pain perception. The primary analyses in this first set of papers seek to identify putative risk factors that are associated with chronic TMD in the OPPERA case-control study. Other analyses evaluate variations in putative risk factors according to sex, race/ ethnicity, and age. For the measures of pain amplification, cardiovascular function and psychological characteristics, we present findings from initial principal components analyses that explore dimensions that might underlie the numerous measures within each domain. After completion of follow-up data collection from people in the OPPERA prospective cohort study, we will publish other manuscripts that focus on the identification of biopsychosocial and genetic risk factors for TMD onset and persistence.

\section{Acknowledgments}

The authors would like to thank the OPPERA Research Staff for their invaluable contributions to this work. In addition, we express our gratitude to the research participants who have devoted time and effort in support of this research.

\section{References}

1. Alsobrook JP, Zohar AH, Leboyer M, Chabane N, Ebstein RP, Pauls DL. Association between the COMT locus and obsessive-compulsive disorder in females but not males. Am J Med Genet. 2002; 114(1):116-120. [PubMed: 11840516]

2. Andersson HI. The course of non-malignant chronic pain: a 12-year follow-up of a cohort from a general population. European Journal of Pain. 2004; 8:47-53. [PubMed: 14690674]

3. Beaton RD, Egan KJ, Nakagawa-Kogan H, Morrison KN. Self-reported symptoms of stress with temporomandibular disorders: comparisons to healthy men and women. Journal of Prosthet Dent. 1991; 65:289-293.

4. Bush FM, Harkins SW, Harrington WG, Price DD. Analysis of gender effects on pain perception and symptom presentation in temporomandibular pain. Pain. 1993; 53:73-80. [PubMed: 8316393]

5. Carlson CR, Okeson JP, Falace DA, Nitz AJ, Curran SL, Anderson D. Comparison of psychologic and physiologic functioning between patients with masticatory muscle pain and matched controls. Jour of Orofacial Pain. 1993; 7:15-22. [PubMed: 8467294]

6. Carlsson, GE.; Le Resche, L. Epidemiology of temporomandibular disorders. In: Sessle, BJ.; Bryant, PS.; Dionne, RA., editors. Temporomandibular Disorders and Related Pain Conditions. Seattle: IASP Press; 1995. p. 211-226.

7. Caspi A, Sugden K, Moffitt TE, Taylor A, Craig IW, Harrington H, McClay J, Mill J, Martin J, Braithwaite A, Poulton R. Influence of life stress on depression: moderation by a polymorphism in the 5-HTT gene. Science. 2003; 301(5631):386-389. [PubMed: 12869766]

8. Chesler EJ, Wilson SG, Lariviere WR, Rodriguez-Zas SL, Mogil JS. Identification and ranking of genetic and laboratory environment factors influencing a behavioral trait, thermal nociception, via computational analysis of a large data archive. Neurosci Biobehav Rev. 2002; 26(8):907-923. [PubMed: 12667496]

9. Costigan M, Belfer I, Griffin RS, Dai F, Barrett LB, Coppola G, Wu T, Kiselycznyk C, Poddar M, Lu Y, Diatchenko L, Smith S, Cobos EJ, Zaykin D, Allchorne A, Shen PH, Nikolajsen L, Karppinen J, Mannikko M, Kelempisioti A, Goldman D, Maixner W, Geschwind DH, Max MB, Seltzer Z, Woolf CJ. Multiple chronic pain states are associated with a common amino acidchanging allele in KCNS1. Brain. 2010; 133(9):2519-2527. [PubMed: 20724292]

10. Deckert J, Catalano M, Syagailo YV, Bosi M, Okladnova O, Di Bella D, Nothen MM, Maffei P, Franke P, Fritze J, Maier W, Propping P, Beckmann H, Bellodi L, Lesch KP. Excess of high activity monoamine oxidase A gene promoter alleles in female patients with panic disorder. Hum Mol Genet. 1999; 8(4):621-624. [PubMed: 10072430] 
11. Diatchenko L, Slade GD, Nackley AG, Bhalang K, Sigurdsson A, Belfer I, Goldman D, Xu K, Shabalina SA, Shagin D, Max MB, Makarov SS, Maixner W. Genetic basis for individual variations in pain perception and the development of a chronic pain condition. Hum Mol Genet. 2005; 14(1):135-143. [PubMed: 15537663]

12. Diatchenko L, Nackley AG, Slade GD, Fillingim RB, Maixner W. Idiopathic pain disorders-pathways of vulnerability. Pain. 2006; 123(3):226-230. [PubMed: 16777329]

13. Diatchenko L, Nackley AG, Tchivileva IE, Shabalina SA, Maixner W. Genetic architecture of human pain perception. Trends Genet. 2007; 23(12):605-613. [PubMed: 18023497]

14. Domschke K, Freitag CM, Kuhlenbumer G, Schirmacher A, Sand P, Nyhuis P, Jacob C, Fritze J, Franke P, Rietschel M, Garritsen HS, Fimmers R, Nthen MM, Lesch KP, Stgbauer F, Deckert J. Association of the functional V158M catechol-O-methyl-transferase polymorphism with panic disorder in women. Int J Neuropsychopharmacol. 2004:1-6. [PubMed: 14720317]

15. Dworkin SF, Von Korff M, LeResche L. Epidemiologic studies of chronic pain: A dynamicecologic perspective. Ann Behav Med. 1992; 14:3-11.

16. Dworkin SF, Huggins KH, Le Resche L, Von Korff M, Howard J, Truelove E, Sommers E. Epidemiology of signs and symptoms in temporomandibular disorders: clinical signs in cases and controls. JADA. 1990; 120:273-281. [PubMed: 2312947]

17. Dworkin SF, Fricton JR, Hollender L, Huggins KH, LeResche L, Lund J, Mohl N, Ohrbach R, Palla SF, Sommers EE, Stohler C, Truelove EL, Von Korff M, Widmer CG. Research diagnostic criteria for temporomandibular disorders: review, criteria, examinations and specifications, critique. Journal of Craniomandibular Disorders Facial Pain and Oral Pain. 1992; 6:302-355.

18. Dworkin, SF.; LeResche, L. APS Bulletin. April/May 12. 1993 Temporomandibular disorder pain: Epidemiologic data.

19. Edwards CL, Fillingim RB, Keefe F. Race, ethnicity and pain. Pain. 2001; 94(2):133-137. [PubMed: 11690726]

20. Edwards RR, Fillingim RB, Yamauchi S, Sigurdsson A, Bunting S, Mohorn SG, Maixner W. Effects of gender and acute dental pain on thermal pain responses. Clin J Pain. 1999; 15(3):233237. [PubMed: 10524477]

21. Epker J, Gatchel RJ, Ellis E III. A model for predicting chronic TMD: practical application in clinical settings. J Am Dent Assoc. 1999; 130(10):1470-1475. [PubMed: 10570591]

22. Escobar JI, Burnam MA, Karno M, Forsythe A, Golding JM. Somatization in the community. Arch Gen Psychiatry. 1987; 44(8):713-718. [PubMed: 3498454]

23. Estevez M, Gardner KL. Update on the genetics of migraine. Hum Genet. 2004; 114(3):225-235. [PubMed: 14624354]

24. Fillingim RB, Maixner W, Kincaid S, Sigurdsson A, Harris MB. Pain sensitivity in patients with temporomandibular disorders: relationship to clinical and psychosocial factors. Clin J Pain. 1996; 12:260-269. [PubMed: 8969871]

25. Fricton, JR.; Schiffman, EL. Epidemiology of temporomandibular disorders. In: Fricton, JR.; Dubner, R., editors. Advances in Pain Research and Therapy; Orofacial Pain and Temporomandibular Disorders. New York: Raven Press; 1995. p. 1-14.

26. Garofalo JP, Gatchel RJ, Wesley AL, Ellis E. Predicting chronicity in acute temporomandibular joint disorders using the research diagnostic criteria. J Am Dent Assoc. 1998; 129(4):438-447. [PubMed: 9573694]

27. Gordon JA, Hen R. Genetic approaches to the study of anxiety. Annu Rev Neurosci. 2004; 27:193222. [PubMed: 15217331]

28. Green CR, Anderson KO, Baker TA, Campbell LC, Decker S, Fillingim RB, Kaloukalani DA, Lasch KE, Myers C, Tait RC, Todd KH, Vallerand AH. The unequal burden of pain: confronting racial and ethnic disparities in pain. Pain Medicine. 2003; 4(3):277-294. [PubMed: 12974827]

29. Gureje O, Von Korff M, Simon GE, Gater R. Persistent pain and well-being: A World Health Organization study in primary care. JAMA. 1998; 280:147-151. [PubMed: 9669787]

30. Gursoy S, Erdal E, Herken H, Madenci E, Alasehirli B, Erdal N. Significance of catechol-Omethyltransferase gene polymorphism in fibromyalgia syndrome. Rheumatol Int. 2003; 23(3): 104-107. [PubMed: 12739038] 
31. Hamilton SP, Slager SL, Heiman GA, Deng Z, Haghighi F, Klein DF, Hodge SE, Weissman MM, Fyer AJ, Knowles JA. Evidence for a susceptibility locus for panic disorder near the catechol-Omethyltransferase gene on chromosome 22. Biol Psychiatry. 2002; 51(7):591-601. [PubMed: 11950461]

32. Heiberg A, Heloe B, Heiberg AN, Heloe LA, Magnus P, Berg K, Nance WE. Myofascial pain dysfunction (MPD) syndrome in twins. Community Dent Oral Epidemiol. 1980; 8(8):434-436. [PubMed: 6942960]

33. Heikkila JK, Koskenvuo M, Heliovaara M, Kurppa K, Riihimaki H, Heikkila K, Rita H, Videman T. Genetic and environmental factors in sciatica. Evidence from a nationwide panel of 9365 adult twin pairs 4. Ann Med. 1989; 21(5):393-398. [PubMed: 2605032]

34. Herken H, Erdal E, Mutlu N, Barlas O, Cataloluk O, Oz F, Guray E. Possible association of temporomandibular joint pain and dysfunction with a polymorphism in the serotonin transporter gene. Am J Orthod Dentofacial Orthop. 2001; 120(3):308-313. [PubMed: 11552131]

35. Isong U, Gansky SA, Plesh O. Temporomandibular joint and muscle disorder-type pain in U.S. adults: the National Health Interview Survey. J Orofac Pain. 2008; 22(4):317-322. [PubMed: 19090404]

36. Janal MN, Raphael KG, Nayak S, Klausner J. Prevalence of myofascial temporomandibular disorder in US community women. J Oral Rehabil. 2008; 35(11):801-809. [PubMed: 18976276]

37. John MT, Miglioretti DL, LeResche L, Von Korff M, Critchlow CW. Widespread pain as a risk factor for dysfunctional temporomandibular disorder pain. Pain. 2003; 102(3):257-263. [PubMed: 12670667]

38. Karayiorgou M, Sobin C, Blundell ML, Galke BL, Malinova L, Goldberg P, Ott J, Gogos JA. Family-based association studies support a sexually dimorphic effect of COMT and MAOA on genetic susceptibility to obsessive-compulsive disorder. Biol Psychiatry. 1999; 45(9):1178-1189. [PubMed: 10331110]

39. Keefe FJ, Dolan E. Pain behavior and pain coping strategies in low back pain and myofascial pain dysfunctional patients. Pain. 1986; 24:49-56. [PubMed: 2937006]

40. Lawford BR, McD YR, Noble EP, Kann B, Arnold L, Rowell J, Ritchie TL. D2 dopamine receptor gene polymorphism: paroxetine and social functioning in posttraumatic stress disorder. Eur Neuropsychopharmacol. 2003; 13(5):313-320. [PubMed: 12957328]

41. Lesch KP. Gene-environment interaction and the genetics of depression. J Psychiatry Neurosci. 2004; 29(3):174-184. [PubMed: 15173894]

42. Macfarlane TV, Blinkhorn AS, Davies RM, Kincey J, Worthington HV. Predictors of outcome for orofacial pain in the general population: a four-year follow-up study. J Dent Res. 2004; 83:712719. [PubMed: 15329378]

43. Maixner W, Fillingim R, Booker D, Sigurdsson A. Sensitivity of patients with painful temporomandibular disorders to experimentally evoked pain. Pain. 1995; 63:341-351. [PubMed: 8719535]

44. Maixner, W.; Sigurdsson, A.; Fillingim, R.; Lundeen, T.; Booker, D. Regulation of acute and chronic orofacial pain. In: Fricton, JR.; Dubner, RB., editors. Orofacial Pain and Temporomandibular Disorders. New York: Raven Press, Ltd; 1995. p. 85-102.

45. Maixner W, Fillingim R, Sigurdsson A, Kincaid S, Silva S. Sensitivity of patients with painful temporomandibular disorders to experimentally evoked pain: evidence for altered temporal summation of pain. Pain. 1998; 76(1):71-81. [PubMed: 9696460]

46. McCreary CP, Clark GT, Oakley ME, Flack V. Predicting response to treatment for temporomandibular disorders. J Craniomandib Disord. 1992; 6(3):161-169. [PubMed: 1401133]

47. McCulley MC, Day IN, Holmes C. Association between interleukin 1-beta promoter (-511) polymorphism and depressive symptoms in Alzheimer's disease. Am J Med Genet. 2004; 124B(1):50-53. [PubMed: 14681913]

48. McGrath M, Kawachi I, Ascherio A, Colditz GA, Hunter DJ, De VI. Association between catechol-O-methyltransferase and phobic anxiety. Am J Psychiatry. 2004; 161(9):1703-1705. [PubMed: 15337664]

49. Michalowicz BS, Pihlstrom BL, Hodges JS, Bouchard TJ Jr. No heritability of temporomandibular joint signs and symptoms. J Dent Res. 2000; 79(8):1573-1578. [PubMed: 11023277] 
50. Mogil JS. The genetic mediation of individual differences in sensitivity to pain and its inhibition. Proc Natl Acad Sci. 1999; 96:7744-7751. [PubMed: 10393892]

51. Mulder EJ, Van Baal C, Gaist D, Kallela M, Kaprio J, Svensson DA, Nyholt DR, Martin NG, MacGregor AJ, Cherkas LF, Boomsma DI, Palotie A. Genetic and environmental influences on migraine: a twin study across six countries. Twin Res. 2003; 6(5):422-431. [PubMed: 14624726]

52. Mundo E, Richter MA, Zai G, Sam F, McBride J, Macciardi F, Kennedy JL. 5HT1Dbeta Receptor gene implicated in the pathogenesis of Obsessive-Compulsive Disorder: further evidence from a family-based association study. Mol Psychiatry. 2002; 7(7):805-809. [PubMed: 12192628]

53. Neely GG, Hess A, Costigan M, Keene AC, Goulas S, Langeslag M, Griffin RS, Belfer I, Dai F, Smith SB, Diatchenko L, Gupta V, Xia CP, Amann S, Kreitz S, Heindl-Erdmann C, Wolz S, Ly CV, Arora S, Sarangi R, Dan D, Novatchkova M, Rosenzweig M, Gibson DG, Truong D, Schramek D, Zoranovic T, Cronin SJ, Angjeli B, Brune K, Dietzl G, Maixner W, Meixner A, Thomas W, Pospisilik JA, Alenius M, Kress M, Subramaniam S, Garrity PA, Bellen HJ, Woolf CJ, Penninger JM. A genome-wide Drosophila screen for heat nociception identifies alpha2delta3 as an evolutionarily conserved pain gene. Cell. 2010; 143(4):628-638. [PubMed: 21074052]

54. Nielsen CS, Stubhaug A, Price DD, Vassend O, Czajkowski N, Harris JR. Individual differences in pain sensitivity: Genetic and environmental contributions. Pain. 2007

55. Norbury TA, MacGregor AJ, Urwin J, Spector TD, McMahon SB. Heritability of responses to painful stimuli in women: a classical twin study. Brain. 2007; 130(Pt 11):3041-3049. [PubMed: 17932101]

56. Ohrbach R, Dworkin SF. Five-year outcomes in TMD: relationship of changes in pain to changes in physical and psychological variables. Pain. 1998; 74(2):315-326. [PubMed: 9520246]

57. Okeson, JP.; Adler, RC.; Anderson, GC.; Baragona, PM.; Broker, EB.; Falace, DA.; GraffRadford, SB.; Kaplan, AS.; McDonald, C.; McNeill, C.; Milliner, EK.; Rosenbaum, RS.; Seligman, DA. Differential Diagnosis and Management Considerations of Temporomandibular Disorders. In: Okeson, JP., editor. Orofacial Pain. Chicago: Quintessence; 1996. p. 113-184.

58. Plesh O, Crawford PB, Gansky SA. Chronic pain in a biracial population of young women 1. Pain. 2002; 99(3):515-523. [PubMed: 12406528]

59. Rammelsberg P, LeResche L, Dworkin S, Mancl L. Longitudinal outcome of temporomandibular disorders: a 5-year epidemiologic study of muscle disorders defined by research diagnostic criteria for temporomandibular disorders. J Orofac Pain. 2003; 17(1):9-20. [PubMed: 12756926]

60. Raphael KG, Marbach JJ, Gallagher RM, Dohrenwend BP. Myofascial TMD does not run in families. Pain. 1999; 80(1):15-22. [PubMed: 10204713]

61. Risch NJ. Searching for genetic determinants in the new millennium. Nature. 2000:847-856. [PubMed: 10866211]

62. Rosa A, Peralta V, Papiol S, Cuesta MJ, Serrano F, Martinez-Larrea A, Fananas L. Interleukin-1beta (IL-1beta) gene and increased risk for the depressive symptom-dimension in schizophrenia spectrum disorders. Am J Med Genet. 2004; 124B(1):10-14. [PubMed: 14681906]

63. Sarlani E, Greenspan JD. Evidence for generalized hyperalgesia in temporomandibular disorders patients. Pain. 2003; 102(3):221-226. [PubMed: 12670662]

64. Slade GD, Diatchenko L, Bhalang K, Sigurdsson A, Fillingim RB, Belfer I, Max MB, Goldman D, Maixner W. Influence of psychological factors on risk of temporomandibular disorders. J Dent Res. 2007; 86(11):1120-1125. [PubMed: 17959908]

65. Smoller JW, Rosenbaum JF, Biederman J, Susswein LS, Kennedy J, Kagan J, Snidman N, Laird N, Tsuang MT, Faraone SV, Schwarz A, Slaugenhaupt SA. Genetic association analysis of behavioral inhibition using candidate loci from mouse models. Am J Med Genet. 2001; 105(3):226-235. [PubMed: 11353440]

66. Solberg, WK. Epidemiology, incidence and prevalence of temporomandibular disorders. In: Laskin, D.; Greenfield, W.; Gale, W., editors. The President's Conference of the Examination, Diagnosis, and Management of Temporomandibular Disorders. Chicago: American Dental Association; 1983.

67. Solovieva S, Leino-Arjas P, Saarela J, Luoma K, Raininko R, Riihimaki H. Possible association of interleukin 1 gene locus polymorphisms with low back pain. Pain. 2004; 109(1):8-19. [PubMed: 15082121] 
68. Strobel A, Gutknecht L, Rothe C, Reif A, Mossner R, Zeng Y, Brocke B, Lesch KP. Allelic variation in 5-HT1A receptor expression is associated with anxiety- and depression-related personality traits. J Neural Transm. 2003; 110(12):1445-1453. [PubMed: 14666415]

69. Vassend O, Krogstad BS, Dahl BL. Negative affectivity, somatic complaints, and symptoms of temporomandibular disorders. J Psychosom Res. 1995; 39:889-899. [PubMed: 8636921]

70. Von Korff M, Dworkin SF, Le Resche L, Kruger A. An epidemiologic comparison of pain complaints. Pain. 1988; 32:173-183. [PubMed: 3362555]

71. Von Korff M, Le Resche L, Dworkin SF. First onset of common pain symptoms: a prospective study of depression as a risk factor. Pain. 1993; 55:251-258. [PubMed: 8309712]

72. Wilson L, Dworkin SF, Whitney C, LeResche L. Somatization and pain dispersion in chronic temporomandibular disorder pain. Pain. 1994; 57(1):55-61. [PubMed: 8065797]

73. Wust S, Van Rossum EF, Federenko IS, Koper JW, Kumsta R, Hellhammer DH. Common polymorphisms in the glucocorticoid receptor gene are associated with adrenocortical responses to psychosocial stress. J Clin Endocrinol Metab. 2004; 89(2):565-573. [PubMed: 14764763]

74. Yu YW, Chen TJ, Hong CJ, Chen HM, Tsai SJ. Association study of the interleukin-1 beta (C-511T) genetic polymorphism with major depressive disorder, associated symptomatology, and antidepressant response. Neuropsychopharmacology. 2003; 28(6):1182-1185. [PubMed: 12700687]

75. Zubenko GS, Maher B, Hughes HB III, Zubenko WN, Stiffler JS, Kaplan BB, Marazita ML. Genome-wide linkage survey for genetic loci that influence the development of depressive disorders in families with recurrent, early-onset, major depression. Am J Med Genet. 2003; 123B(1):1-18. [PubMed: 14582139]

76. Zubieta JK, Heitzeg MM, Smith YR, Bueller JA, Xu K, Xu Y, Koeppe RA, Stohler CS, Goldman D. COMT val158met genotype affects mu-opioid neurotransmitter responses to a pain stressor. Science. 2003; 299(5610):1240-1243. [PubMed: 12595695] 


\section{Appendix Materials}

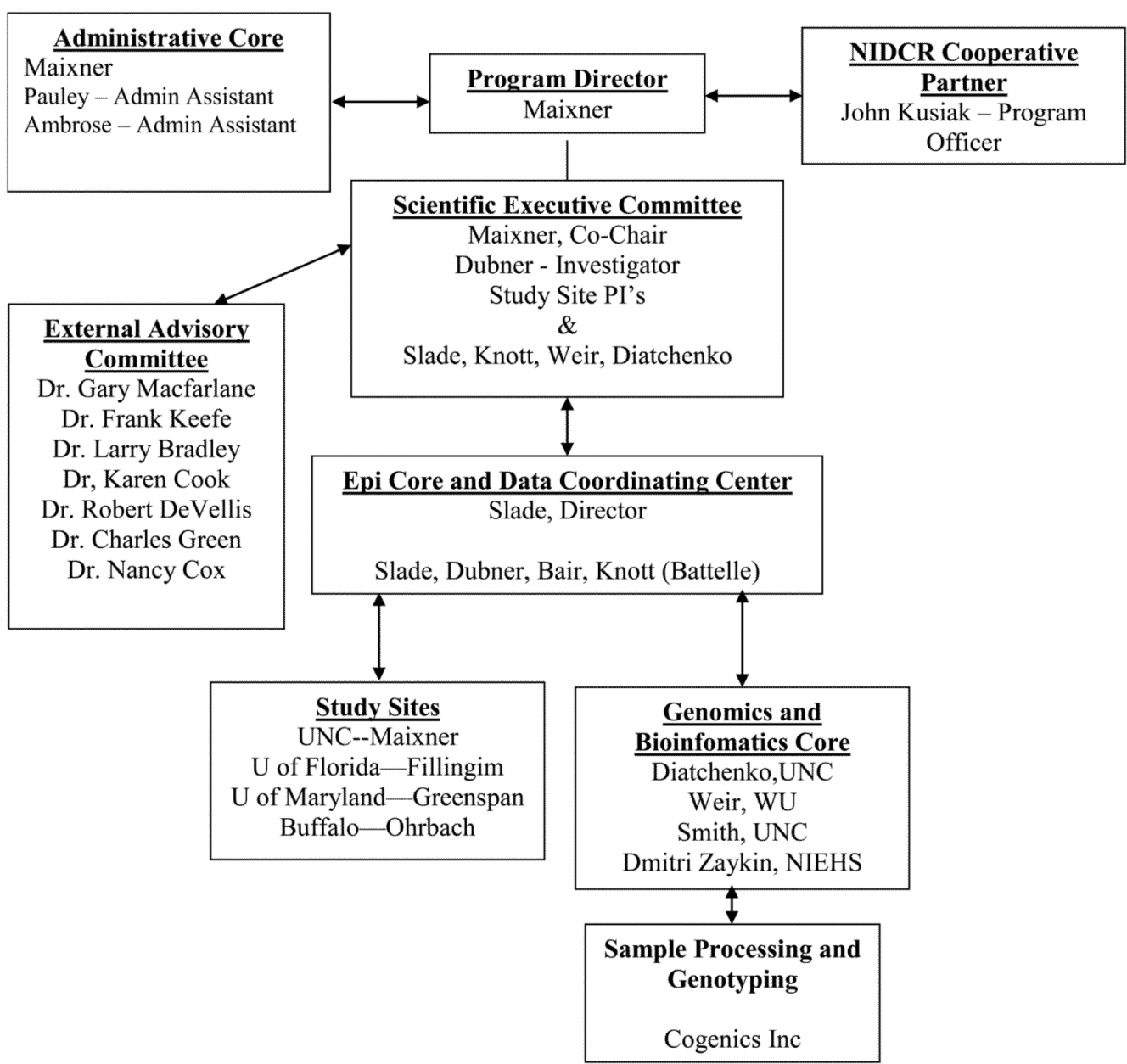

Figure.

Organizational, Management, Oversight Structure: 


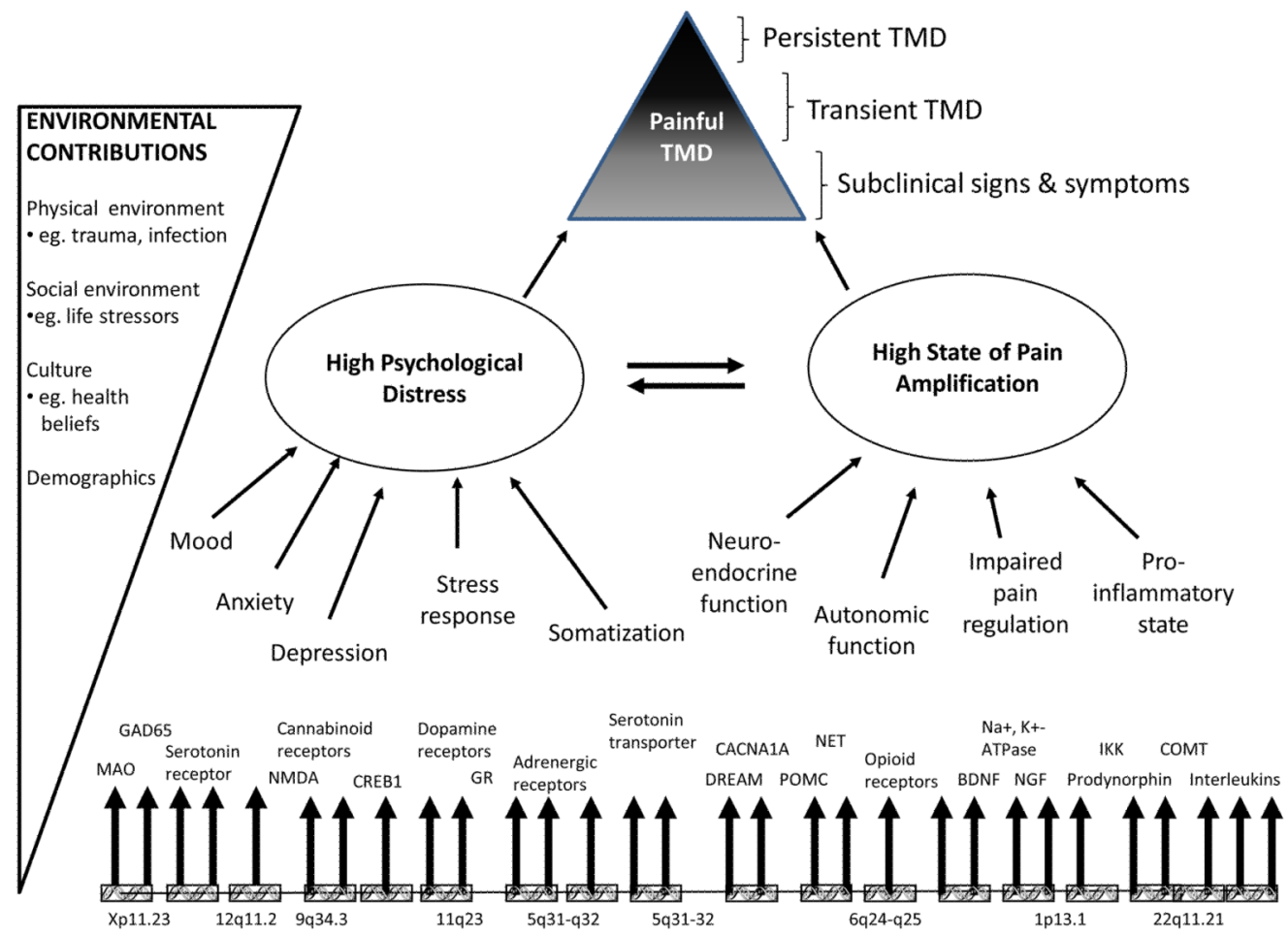

Figure 1.

This model displays two principal intermediate phenotypes (psychological distress and pain amplification) that contribute to onset and persistence of TMD. Each intermediate phenotypes represents a constellation of more specific risk factors, all of which are subject to genetic regulation. Interactions between intermediate phenotypes take place in the presence of environmental contributions that further contribute to onset and persistence of painful TMD. Time is not shown in the model, because its effects occur implicitly on a third dimension that is not readily shown in the diagram. 